\title{
Oral Lecithin and Linoleic Acid in Friedreich's Ataxia: III. Biochemical Results
}

\author{
S.B. MELANCON, L. DALlAiRE, M. POTIER, J. COUSINEAU, M. VANASSE, G. GEOFFROY, G. FONTAINE, B. GRIGNON
}

SUMMARY: Lecithin and safflower oil brought about the same changes in serum $L A D$ activity and kinetics in patients with Friedreich's Ataxia as in controls when results of this double-blind crossover study were analyzed according to group assignation. According to functional stages, pretrial $L A D$ activity decreased with advancing severity while $\mathrm{Km}$ for lipoamide increased. Lecithin and safflower oil supplements corrected the elevated $\mathrm{Km}$ for lipoamide but produced a further reduction in LAD activity. These changes may have

RÉSUMÉ: En analysant ataxiques et témoins par groupe, les résultats de cette $e^{E}$ tude à double insu démontrent que la lécithine et l'huile de carthame produisent les mêmes changements dans l'activité et la cinétique de la $L A D$ sérique. Cependant le comportement de l'enzyme est différent selon les stades fonctionnels avant et après supplémentation. L'activité sérique initiale en $L A D$ décrôt avec la sévérité de l'atteinte fonctionnelle tandis que le $\mathrm{Km}$ pour le lipoamide tend à s'accrôttre. La lécithine et l'huile de carthame ramenent ce $K m$ dans des valeurs contrôles mais induisent une been due to the increased intake of linoleic acid, a precursor of lipoic acid, which is present in high percentage in both lecithin and safflower oil. Results of the biochemical study thus agreed with the clinical data gathered during the course of the one-year trial in suggesting that linoleic acid may well have been the active factor through which biochemical and clinical improvement was previously observed in patients with Friedreich's Ataxia supplemented with lecithin.

diminution significative de l'activité $L A D$ sérique chez les patients des stades $I I$ et III. Ce phénomène doit être explicable par la haute teneur en acide linoléique, précurseur naturel de l'acide lipoique, dans les suppléments oraux utilisés. Ces résultats suggèrent aussi que l'effet bénéfique occasionnellement observé chez des ataxiques recevant de la lécithine découle de l'apport accru d'acide linoléique. Cette explication s'applique aussi bien aux observations cliniques préalablement rapportées qu'aux résultats biochimiques.
Le centre de recherche pédiatrique, Hôpital Sainte Justine, Universitè de Montréal.

Reprint requests for the entire supplement on Friedreich's Ataxia (Phase Three, Part Two) to: Prof. André Barbeau, Clinical Research Institute of Montreal, 110 West Pine Avenue, Montreal, Quebec. Canada, H2W $1 \mathrm{R} 7$.

\section{INTRODUCTION}

Since the original report by Kark et al, (1974) postulating a relationship between pyruvate dehydrogenase (PDH) deficiency and Friedreich's Ataxia, many investigators have studied PDH in different tissues and cells from patients with "typical" Friedreich's Ataxia and other types of progressive ataxias. The general conclusion was to the effect that the degree of PDH deficiency in Friedreich's Ataxia was either not significant enough to explain the severity of the clinical manifestations or was not present in enough patients as to suggest a primary defect (Barbeau, 1980). Attempts to localize the PDH defect at the level of one of its three major components have incriminated $E_{3}$, dihydrolipoyl-dehydrogenase (LAD) as the most probable defective element (Melançon et al, 1977; Kark et al, 1979). The degree of reduction in LAD activity in Friedreich's Ataxia varied from $50 \%$ to $0 \%$ according to authors, choice of patients, material and methods, but never reached the level of deficiency ( 0 to $5 \%$ ) found in children afflicted with infantile lactic acidemia due to hereditary LAD deficiencies (Robinson et al, 1977 and 1981a) or in their heterozygous asymptomatic parents (30\% and $42 \%$ ) (Robinson et al, $1981 \mathrm{~b})$.

In the course of a therapeutic trial with lecithin and placebo (a linoleic acid-rich preparation of safflower oil) we have determined the activity and kinetics of LAD in twenty-two patients with Friedreich's Ataxia and ten normal controls. Details of the patients, materials and methods can be found in previous papers of this issue of the journal. 


\section{RESULTS}

Patients and controls in group A were on lecithin for the first six-month period, then on safflower oil. Group B individuals were put on the opposite regimen. A raise in the mean concentration of NADH necessary to bring about a $50 \%$ inhibition of $\mathrm{LAD}$ activity after the first six-month period of the trial was the only statistically different result encountered according to group assignation (table I). The individual values of LAD activity and kinetics are illustrated in figures 1 to 6 . Mean LAD activity (fig. 1 ), $\mathrm{Km}$ and Vmax for lipoamide (fig. 2 and 3) and $V \max$ for NAD (fig. 5) decreased with time in patients and controls whether on lecithin or safflower oil. The $\mathrm{Km}$ for NAD (fig. 4) and ki for NADH (fig. 6) increased after 3 and 6 months and regained pretrial levels at the end of the year.

The same results have been tabulated according to functional stages (table II). Pre-trial LAD activity was higher in early stages patients, decreased with time in all stages after lecithin or safflower oil and reached statistically significant lower levels ( $p$ $<.01$ ) in stage II and III patients. Pretrial $\mathrm{Km}$ for lipoamide raised with increasing stages and came back to control values (stage 0 ) after lecithin or safflower oil. Vmax for lipoamid followed the pattern of LAD activity. $\mathrm{Km}$ for NAD increased with lecithin and safflower oil, up to a statistically significant level from pre-trial values in stage III patients $(p<.05)$. Vmax for NAD was in parallel with LAD activity. Finally, Ki for NADH increased with both supplements at all stages $(\mathrm{p}<.01$ or .05) except in stage II where pre-trial values were higher and in our single stage IV patient for whom statistical analysis was not possible.

\section{DISCUSSION}

The results according to group assignation confirmed previously reported observations by Kark et al, (1980) in platelets and by our group (Melançon et al, 1980) in serum as to a high $\mathrm{Km}$ for lipoamide in some patients with Friedreich's Ataxia and as to the effect of aging on the mean level of serum LAD activity. Our results ac-

TABLE I

SERUM LIPOAMIDE DEHYDROGENASE (LAD) ACTIVITY AND KTNETICS IN

FRIEDREICH'S ATAYIA ACCORDING TO GROUP ASSIGNATION BEFORE

AND AFTER A SIX-MONTH IRIAL OF IECITHIN OR SAFFLONER OIL

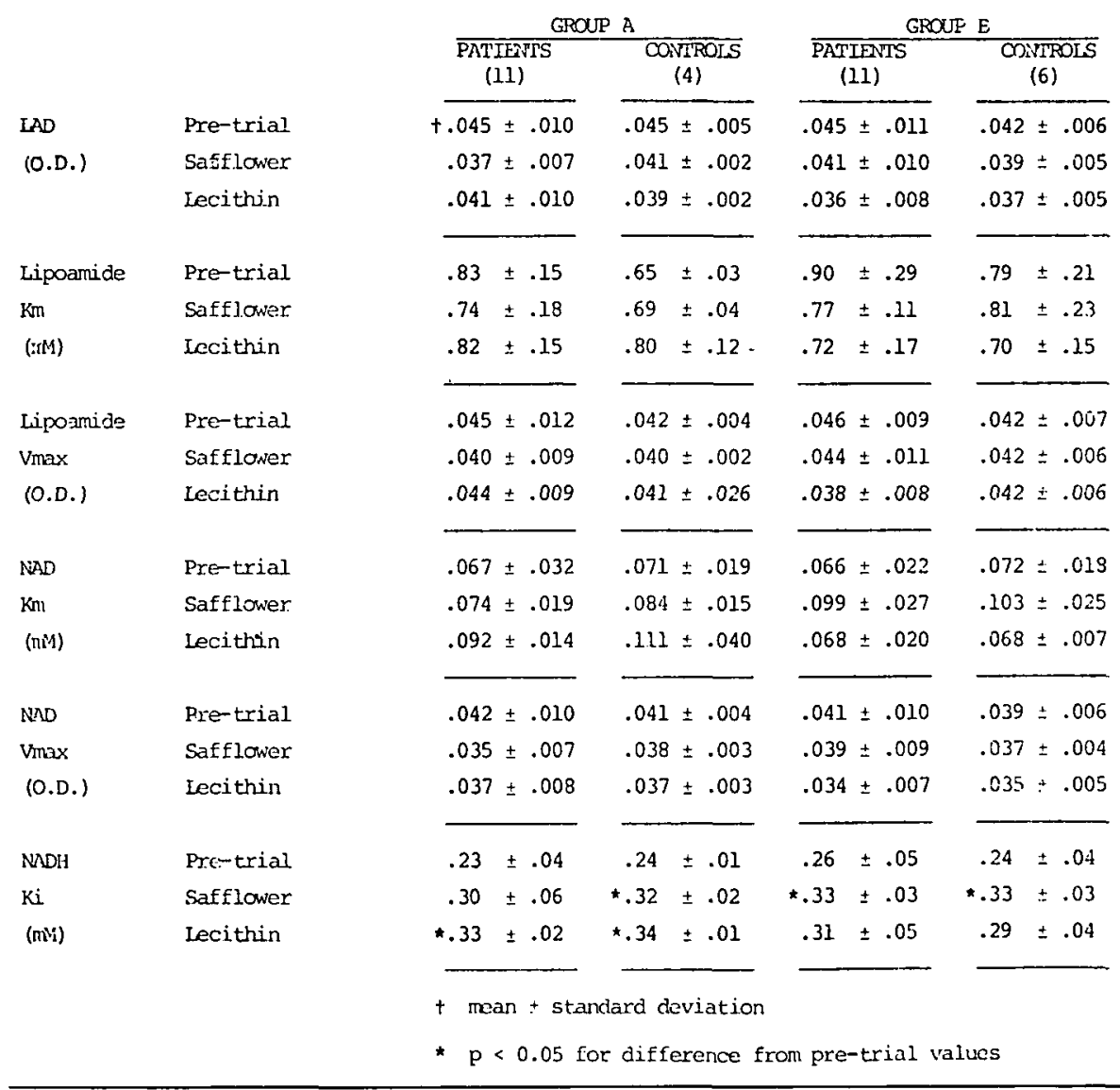

cording to functional stages were more interesting because these same biochemical parameters appeared to change in parallel with the severity of the disease; LAD activity decreased while $\mathrm{Km}$ for lipoamide tended to increase. Lecithin and safflower oil produced the same quantitative changes. Both supplements produced an increase in $\mathrm{Km}$ for NAD and $\mathrm{Ki}$ for $\mathrm{NADH}$ but demonstrated no segregation between patients and controls with the exception of $\mathrm{Km}$ for NAD in stage II patients. Both supplements resulted in lowering of the LAD activity and $\mathrm{Km}$ for lipoamide in patients but showed no appreciable effects on these parameters in controls (stage 0 ).

Since both lecithin and safflower oil are natural products containing a high percentage of linoleic acid, it is tempting to speculate that the difference in response observed between patients and controls (stage 0 ) derives from a linoleic acid-related effect. This unsaturated fatty acid has been shown to act as a precursor of lipoic acid in mammals (Carreau et al, 1977). The role of lipoic acid in energy metabolism in mammals has been clearly associated with the dehydrogenase complexes and it has been demonstrated in bacteria (Langley et al, 1977) and in humans (Taylor et al, 1978) that dihydrolipoyl dehydrogenase (LAD) is a component of all three, pyruvate, $\alpha$ ketoglutarate and branched-chain $\alpha$ ketoacids dehydrogenases. The role of LAD in these three $a$-ketoacid dehydrogenase complexes is biochemically identical, but a genetic mutation affecting the enzyme protein 


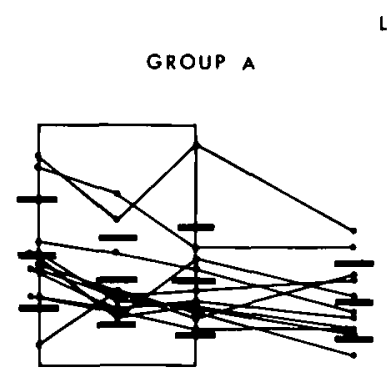

potients

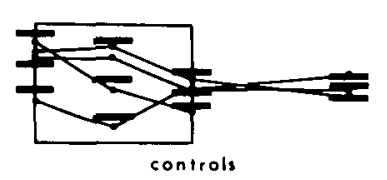

LAD. (O.D.

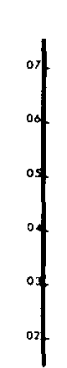

0.5
GROUP B

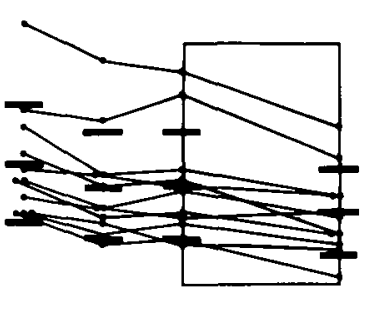

potients

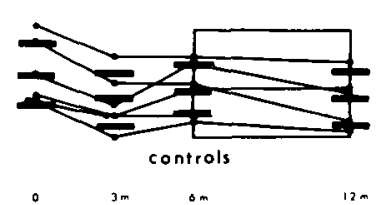

GROUP A
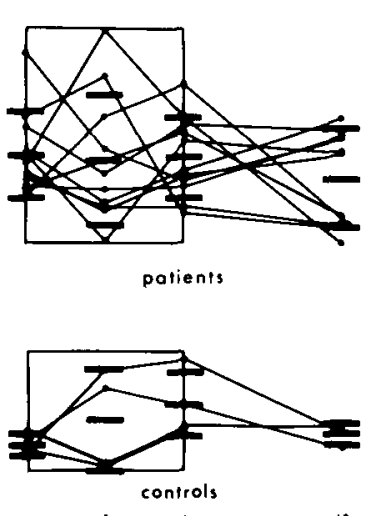

LIPOA MIDE, $\mathrm{Km}(\mathrm{mM})$
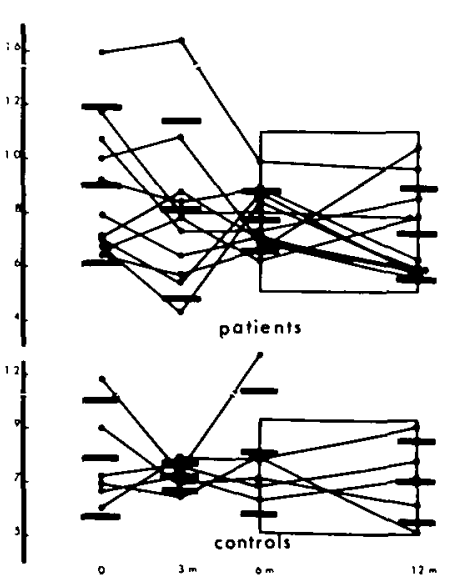

Figure I - Serum LAD activity. Framed area corresponds to lecithin period.

Figure 2 - Serum LAD, Km for lipoamide.
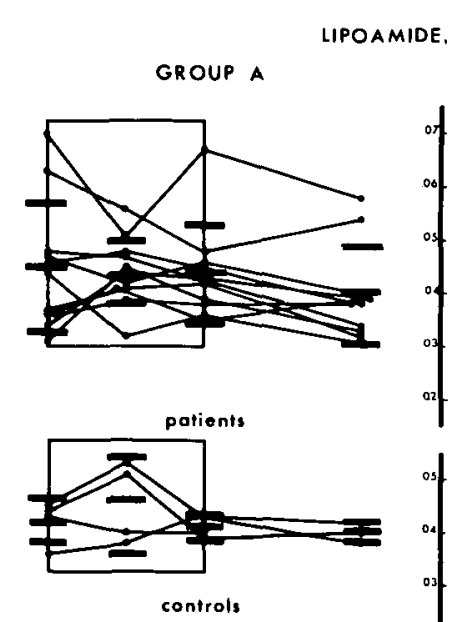

a jm on $12 m$

Figure 3 - Serum LAD, Vmax for lipoamide.
GROUP B

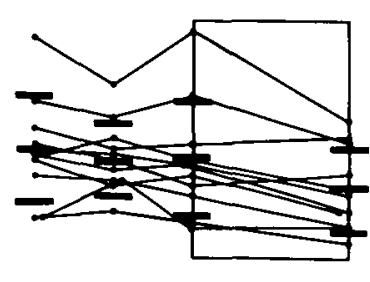

potients

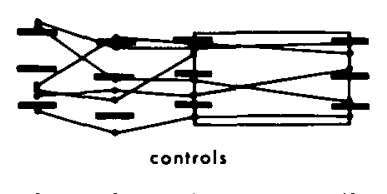

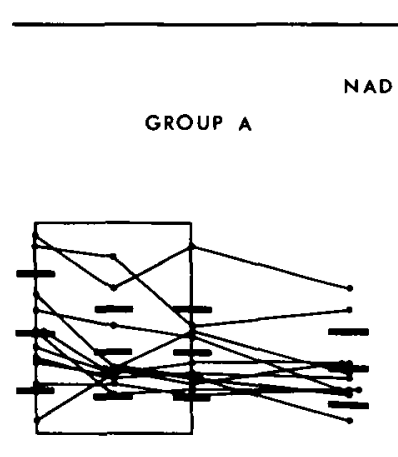

patients

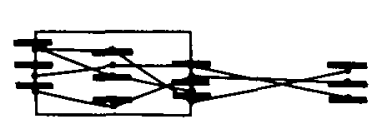

contrals
GROUP B

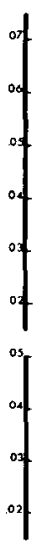

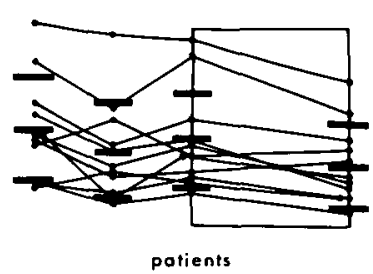

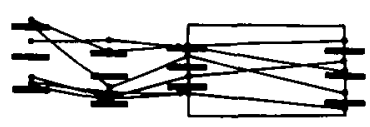

controls

Figure 5 - Serum LAD, Vmax for NAD
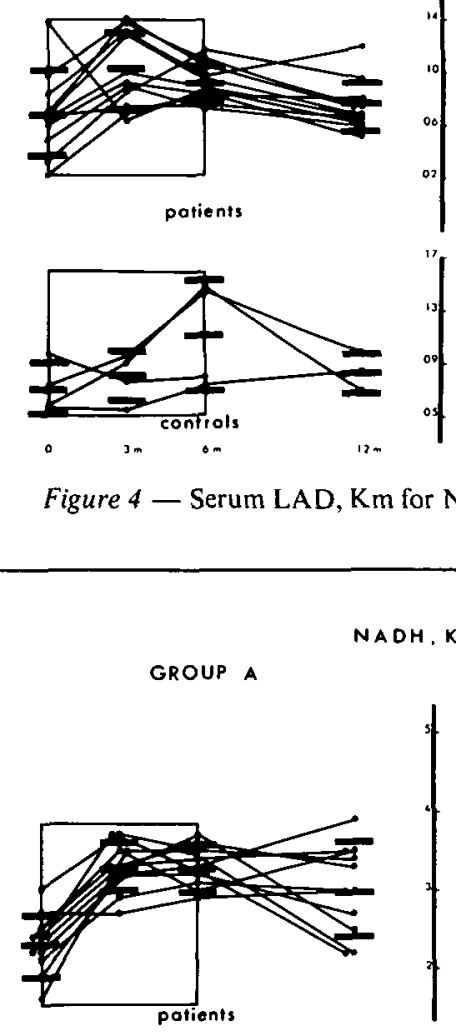

patients

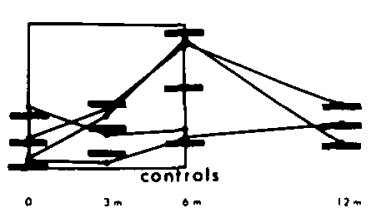

Figure 4 - Serum LAD, Km for NAD
$N A D, K m(m M)$

GROUP A

GROUP B
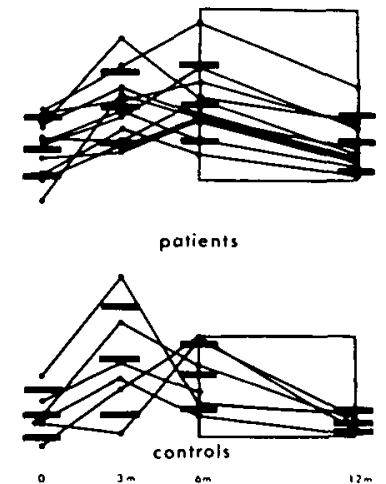

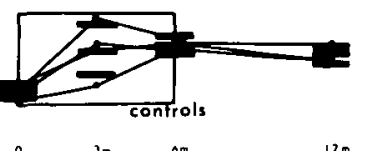

GROUP B

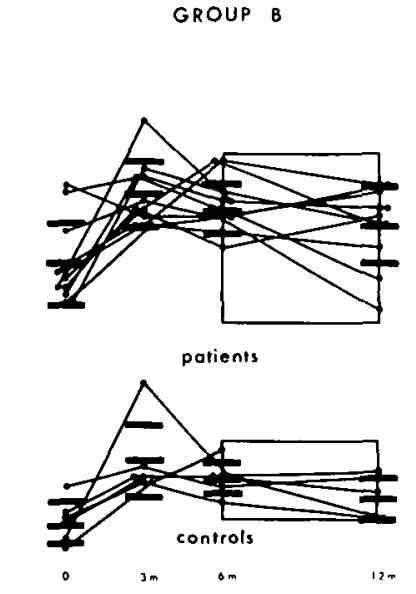

Figure 6 - Serum LAD, Ki for NADH 
TABLE II

SERUM LIPOAMIDE DEHYDROGENASE (LAD) ACTIVITY AND KINETICS IN

FRIEDREICH'S ATAXIA ACCORDING TO FUNCTIONAL STAGFS BEFORE

AND AFTER A SIX-MONTH TRIAL OF LECITHIN OR SAFFLOWER OI

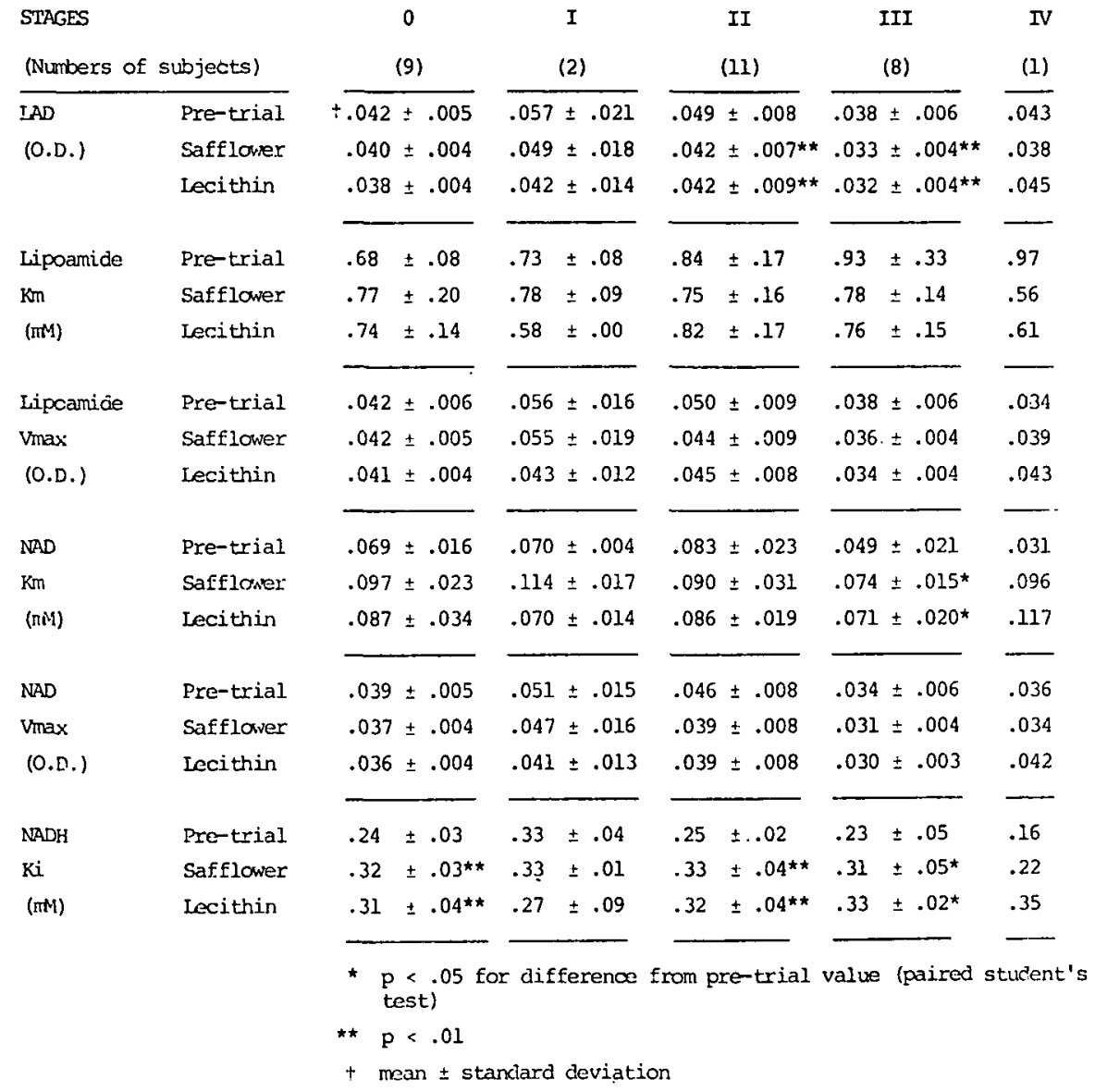

may result in variable amounts of residual activity in each single enzyme as demonstrated by Robinson et al, (1981a) in a case of infantile lactic acidemia (PDH, 24\%; $a$-KGDH, 39\% and BCKDH, 5\%). Pelley et al, (1976) provided evidence that serum LAD originated from liver but the contribution of each dehydrogenase complex to total serum activity has not been defined. It would be premature to postulate that a high dietary intake of linoleic acid in the form of lecithin or safflower oil affects one or the other $\alpha$ ketoacid dehydrogenase in such a way as to reduce its $\mathrm{Km}$ for lipoic acid (lipoamide) in patients with Friedreich's Ataxia down to control levels without correcting the reduction in total LAD activity, and conclude that the reduction in serum LAD is a secondary event in Friedreich's Ataxia (Robinson et al, 1981b).

In summary, we have shown that both lecithin and safflower oil supplements induce specific changes in kinetic parameters of serum LAD but do not correct the reduction in total LAD activity in patients with Friedreich's Ataxia. This observation is in agreement with the results of a clinical evaluation showing no beneficial effect from lecithin as compared to safflower oil in patients with Friedreich's Ataxia as a group (see preceding paper in this issue) and suggests that early stage patients might benefit from linoleic acid supplements both clinically and biochemically.

\section{ACKNOWLEDGEMENTS}

This study was supported by grants from l'Association Canadienne de l'Ataxie de Friedreich and the Muscular Dystrophy Association of Canada.

\section{REFERENCES}

BARBEAU, A. (1980). Friedreich's Ataxia. An overview of the Physiopathology. Can. J. Neurol. Sci. 7: 455-468.

CARREAU, J.P., LAPOUS, D. and POULIN, J. (1977). Signification des acides gras essentiels dans le métabolisme intermédiaire. Hypothèse sur la synthèse de l'acide lipoique. Biochimie 59: 487-496.

KARK, R.A.P., BLASS, J.P. and ENGEL, W.K. (1974). Pyruvate Oxidation in Neuromuscular Diseases: Evidence of Genetic Defect in Two Families in the Clinical Syndrome of Friedreich's Ataxia. Neurology 24: 964-971.

KARK, R.A.P., RODRIGUEZ-BUDELLI, M. and BLASS, J.P. (1978). Evidence for a primary defect of lipoamide dehydrogenase in Friedreich's Ataxia. In Kark, R.A.P., Rosenberg, R.N. and Schutt, L.J., Eds. Advances in Neurology, Vol. 21: 163-180, Raven Press, New York.

KARK, R.A.P. and RODRIGUEZ-BUDELLI, M. (1979). Clinical correlation of partial deficiency of lipoamide dehydrogenase. Neurology 29: 1006-1013.

KARK, R.A.P., RODRIGUEZ-BUDELLI, M., PURLMAN, S., GULLEY, W.F. and TOROK, K. (1980). Preclinical diagnosis and carrier detection in ataxia associated with abnormalities of lipoamide dehydrogenase. Neurology 30: 502-508.

LANGLEY, D. and GUEST, J.R. (1977). Biochemical genetics of the $\alpha$-keto acid dehydrogenase complexes of Escherichia Coli $\mathrm{K}_{12}$-Isolation and biochemical properties of deletion mutants. J. Genet. Microbiology 99: 263-276.

MELANCON, S.B., POTIER, M., DALLAIRE, L., GEOFFROY, G., LEMIEUX, B. and BARBEAU, A. (1977). Serum lipoamide dehydrogenase in Friedreich's Ataxia. Pediat. Res., 11:460. 
MELANÇON, S.B., FONTAINE, G., GEOFFROY, G., VANASSE, M., DALLAIRE, L. and POTIER, M. (1980). Correlation between serum lipoamide dehydrogenase activity and phosphatidylcholine therapy in Friedreich's Ataxia. Can. J. Neurol. Sci., 7: 413-416.

PELlEY, J.W., LITTLE, G.H., LINN, T.C. and HALL, F.F. (1976). Lipoamide dehydrogenase in serum: A preliminary report. Clin. Chem., 22: 275-277.
ROBINSON, B.H., TAYLOR, J. and SHERWOOD, W.G. (1977). Deficiency of dihydrolipoyldehydrogenase. A cause of congenital chronic lactic acidosis in infancy. Pediat. Res., 11: 1198-1202.

ROBINSON, B.H., TAYLOR J., KAHLER, S.G. and KIRKMAN, H.N. (1981a). Lactic Acidemia, Neurologic Deterioration and Carbohydrate Dependance in a Girl with Dihydrolipoyldehydrogenase deficiency. Eur. J. Pediat., 136: 35-39.
ROBINSON, B.H., SHERWOOD, W.G., KAHLER, S., O'FLYNN, M.E. and NADLER, H. (1981b). Lipoamide dehydrogenase deficiency. New Engl. J. Med., 304: 53-56.

TAYLOR, J., ROBINSON, B.H. and SHERWOOD, W.G. (1978). A defect in branched-chain amino acid metabolism in a patient with congenital lactic acidosis due to dihydrolipoyldehydrogenase deficiency. Pediat. Res., 12: 60-62. 